\title{
Moisture and nitrogen stress induces severity of wilt- nematode complex of lentil grown in rice fallow in an inceptisol
}

\author{
RAJ MUKHOPADHYAY ${ }^{1 *}$, VICTOR PHANI ${ }^{1}$, NIRMAL DE ${ }^{2}$, SUMIT KUMAR PANDEY ${ }^{2}$ and RAKESH KUMAR SINGH ${ }^{2}$ \\ ${ }^{1}$ ICAR-Indian Agricultural Research Institute, New Delhi 110 012, India \\ ${ }^{2}$ Banaras Hindu University, Varanasi 221 005, Uttar Pradesh, India
}

Received: 23 December 2016/ Accepted: 9 February 2017/ Published online: 23 March 2017

(c) Indian Phytopathological Society 2017

\begin{abstract}
Lentil (Lens culinaris) is a leading high protein pulse grown by the farmers as a rainfed rabicrop in lowland rice fallows in Indo Gangetic Plains (IGP) of India. Disease complex due to Fusarium oxysporum and Meloidogyne incognita possess a great threat to yield of lentil when grown as fallow crop after rice with residual soil moisture and nitrogen in dryland condition. This paper discusses the role of soil moisture and availability of soil $\mathrm{NO}_{3}-\mathrm{N}$ to the plants on wilt nematode disease complex under a long term rice-lentil cropping system. In our long term experimental conditions which prevailed under dry condition, low level of soil moisture and low availability of soil $\mathrm{NO}_{3}-\mathrm{N}$ to plants illustrated increased in fungus nematode wilt complex severity, which can be mitigated by use of farm yard manure as full source of nitrogen in rice. This leads to the enhancement of the available soil moisture and nitrogen for residual crops like lentil and also reduced wilt nematode complex.
\end{abstract}

Keywords: Disease severity, $\mathrm{FYM}$, lentil, soil moisture, soil $\mathrm{NO}_{3}-\mathrm{N}$, wilt nematode complex

Rainfed rice based cropping system in eastern Uttar Pradesh state of India is characterized by low level of productivity and input usage coupled with vagaries of monsoon results in wide variation and instability in yields. The rice fallows represent an enormous underutilized resource and occupy nearly 7 million hectares in the states of eastern India and millions of farmers grow lentil or chick pea as a rainfed rabicrop in lowland rice fallows. In lowland areas after the harvest of kharif rice, lentil is more suitable and assured potential rabi crop than chickpea, thereby, rice-lentil cropping system is more popular under rainfed system in the lowlands of eastern Uttar Pradesh, Bihar, Jharkhand and West Bengal.

We report disease complex, caused by Fusarium oxysporum and Meloidogyne incognita, as one of the major yield limiting factors for lentil in rainfed rabicropping in 'transect 4' of IGP. The fungus can survive through crop residues of the previous one and serve as inoculum for the successive crop (Stoilova and Chavdarov, 2006). The root-knot nematode (Meloidogyne incognita) is a sedentary endoparasite, and attacks a wide range of crops (Yu et al., 2012). Disease complex due to Meloidogyne javanica and Fusarium oxvsporum possess a great threat to the pulse crops causing severe yield losses (De et al., 2001). Rice acts as main host crop of nematode which serves as source of inoculum for subsequent crop after rice. A break from continuous cultivation of chickpea as a sequential crop after sorghum, or as an intercrop with ${ }^{*}$ Corresponding author: rajssaciari@ gmail.com pigeon pea and sorghum, combined with higher rates of nitrogen application to safflower appears to be an effective strategy for reducing Fusarium populations (Rao et al., 2014). It is also reported that the residue retention of wheat may lead to increase in population of Fusarium oxysporum in long term experiment in wheat-maize cropping system (Govaerts et al., 2008).

The mobility of nitrate to plants is favoured by high level of soil moisture content. Moisture stress causes lesser nitrate mobility through mass flow resulting less utilization of nitrogen by plant (Ge et al., 2014).

Coexistence of Fusarium oxysporum with root-knot nematodes in soil increases the chance of wilt severity for many crops including pulses. Long term experiment with continuous application of organic manure has reported low population density of parasitic nematodes and high bacterivorous nematodes as compared to its peer soil with continuous application of inorganic fertilizer (Mary et al., 2013). The application of organic nutrients capable of delivering $\mathrm{NO}_{3}-\mathrm{N}$ in the rhizosphere soil showed very low level of population of plant pathogenic wilt fungi and root knot nematode as compared to soil treated with urea or DAP $\left(\mathrm{NH}_{4}{ }^{+} \mathrm{N}\right)$ as a source of nitrogen (Goswami et al., 2007).

A long-term experiment on conjunctive use of organic and inorganic fertilizers on soil quality and productivity in rice-lentil cropping sequence under rainfed ecosystem under All India Coordinated Research 
Projects in dry land agriculture is operative at the research farm of Banaras Hindu University, Uttar Pradesh, India. The on farm data represents continuous cropping of lentil in rabi after rice under rainfed condition of Varanasi resulted in population buildup of both the wilt fungus Fusarium oxysporium and nematode Meloidogyne incognita in soil, thereby resulting in reduction of plant height, dry weight, root length and yield of lentil. Further, severity of wilt and nematode complex was correlated with low soil moisture regime vis-à-vis low available $\mathrm{NO}_{3}$ and degree of yield loss. In the present paper we report wilt-nematode complex as a serious yield limiting factor for lentil crop grown in rabi under residual moisture and nutrient in rice-lentil cropping sequence under rainfed ecosystem in 'transect 4' of the Indo Gangetic Plain (IGP) region of India.

\section{MATERIALS AND METHODS}

Site of experiment: The on farm experimental data was collected from the research farm $\left(25^{\circ} 18^{\prime} \mathrm{N}, 83^{\circ} 03^{\prime} \mathrm{E}\right.$, altitude $129 \mathrm{~m}$ above mean sea level) of Banaras Hindu University, Varanasi, Uttar Pradesh, India. The experimental soil was classified as fine sandy loam mixed hyperthermic Udic Ustochrept. The average rainfall is $1081.4 \mathrm{~mm}$ with potential evapotranspiration $1525.2 \mathrm{~mm}$ annually. About $87 \%$ of the total rainfall is received during monsoon season (June end to September).

Conditions of experiment: Nutrients were supplied in rainfed rice (Oryza sativa cv. NDR-97) through organic and inorganic sources and the follow up crop lentil (Lens culinaris cv. HUL-57) was cultivated during October to December with the residual fertilizer in soil. The FYM was incorporated with a wooden plow during June to July every year depending on the rainfall. The gross and net plot size was $12.0 \times 11.1 \mathrm{~m}$ and $10.0 \times 9.9 \mathrm{~m}$, respectively. The treatments were: control (no nutrient supplemented) $-\mathrm{T}_{1} ; 100 \%$ as recommended dose of fertilizers (RDF) (80-40-30 kg ha-1 N:P:K) $-\mathrm{T}_{2} ; 100 \% \mathrm{~N}$ through farm yard manure (FYM) $-\mathrm{T}_{3} ; 50 \% \mathrm{~N}$ through FYM $-\mathrm{T}_{4} ; 50 \% \mathrm{RDF}+50 \% \mathrm{~N}$ through $\mathrm{FYM}-\mathrm{T}_{5}$; and farmers' general practice $\left(20 \mathrm{~kg} \mathrm{~N} \mathrm{ha}^{-1}\right)-\mathrm{T}_{6}$. The on farm data were collected from these treatments where nutrients were applied in a randomized block design with three replications.

Estimation of fungal and nematode population in soil and plant: Plant samples along with rhizospheric soil were collected from three randomly selected sites representing each treatment from field. The fungal population was assessed using $10 \mathrm{~g}$ representative soil from each treatment using serial dilution-agar-plate method (Rolf and Bakken, 1987). The plates were incubated at $28^{\circ} \mathrm{C}$ for 5 days. Moisture content of the test soil was determined gravimetrically.

The nematodes were isolated from soil by "Cobb's decanting and sieving method followed by modified Baermann's technique" (Schindler, 1961), heat killed and fixed with Formalin-Acetic acid fixative (4:1). The gall counts were made from infected plants and matured females were picked for identification of Meloidogyne sp using perineal pattern. Observations were taken under stereo zoom and compound microscope in temporary mounts.

Assessment of disease severity index: A disease severity index (DSI) based on symptoms was calculated using Sherwood and Hagedorn scale (Sherwood and Hagedorn, 1958). DSI is ranged between 0 (no symptoms) to 100 (killing of all plants) and is calculated using the following formula:

$\mathrm{DSI}=($ class no $\mathrm{X}$ no of plants $) /$ (total no of plants $\mathrm{X} 3) \mathrm{X}$ 100.

Estimation of soil and plant parameters: The percent moisture content of soil $(\theta \%)$ was determined by gravimetric method (Black, 1965). $\mathrm{NO}_{3}-\mathrm{N}$ content of finely grinded soil was estimated through the Kjeldhal method following standard procedure (Jackson, 1973). The height of the plants, root length and average plant dry weight were measured with meter scale. Grain yield was also measured for each treatment separately. At harvest, the plant samples were collected from each plot for chemical estimation. The samples were oven dried at $70^{\circ} \mathrm{C}$ for 48 hours and the plant material thus obtained was ground with a grinder, passed through 40 mesh sieves and preserved separately for determination of $\mathrm{N}$ content. Percent $\mathrm{N}$ content was then estimated by Kjeldhal method (Jackson, 1973).

Statistical analysis: Statistical analysis was performed by the Windows-based SPSS program (Version 16.0, Chicago, IL, USA). The SPSS procedure was used for analysis of variance to determine the statistical significance of treatment effects. Karl Pearson Correlation Coefficient ( $r$ ) was calculated in MS-EXCEL between DSI and available soil moisture content. The negative value of ' $r$ ' represents the inverse relationship between two parameters. Error bars in the figures represent the standard error of mean. The $5 \%$ probability level is regarded as statistically significant.

\section{RESULTS}

The long term conjunctive use of organic and inorganic nutrient sources influence yield and yield attributes of lentil crop grown after rice in a rice-lentil crop sequence of Varanasi region. reported during the time in a period of 2008 and 2014 were plant height, root length, dry weight of whole plant, yield and $\% \mathrm{~N}$ content in plants vis-à-vis moisture content $(\theta \%)$ and $\mathrm{NO}_{3}-\mathrm{N}$ content in soil. The trends of variability of these characters are summarized as their mean obtained in 2008 and 2014 for six respective treatments.

Plant parameters: The plants grown under the treatment $\mathrm{T}_{3}$ i.e., application of $100 \% \mathrm{~N}$ through $\mathrm{FYM}$ was found to obtain maximum plant height i.e., 31.56 and $30.33 \mathrm{~cm}$, plant dry weight (total biomass) - 1.24 and $1.28 \mathrm{~g}$, mean root length 7.97 and $7.96 \mathrm{~cm}$ and mean $\% \mathrm{~N}$ content in plant -3.63 and $3.49 \%$ in 2008 and 2014 , respectively, which was at par to the plants grown under recommended dose of fertilizer $\left(T_{2}\right)$ and significantly superior over plants subjected to control $\left(T_{1}\right)$ and farmers' practice $\left(T_{6}\right)$ treatments (Fig. 1.a-d). 


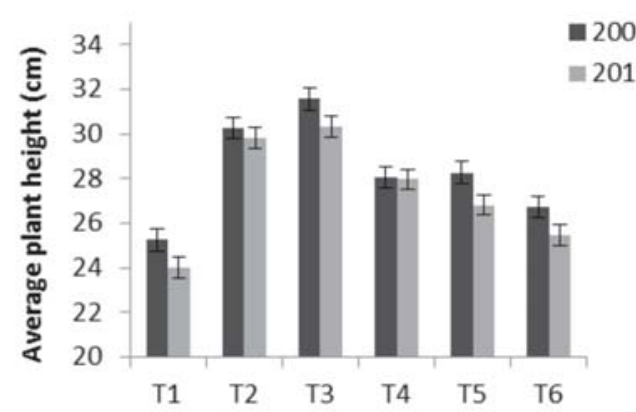

(a) Treatments

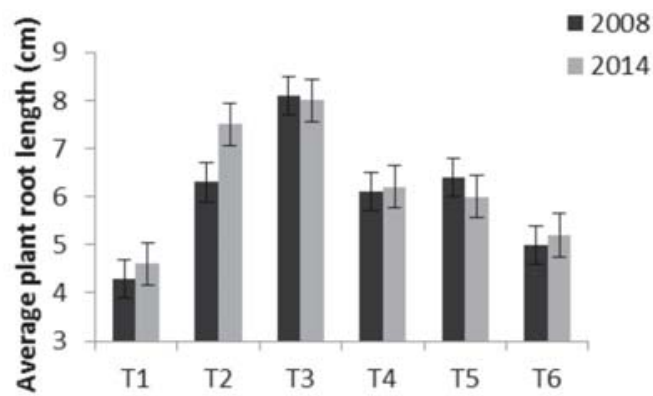

(c) Treatments

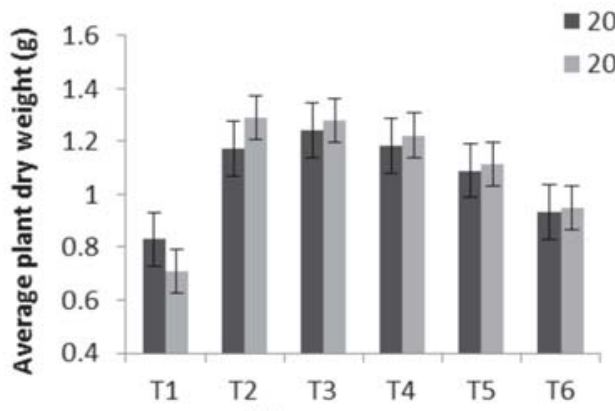

(b) Treaments

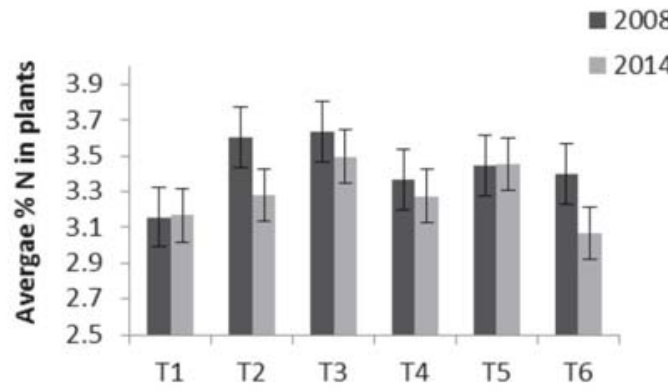

(d) Treatments

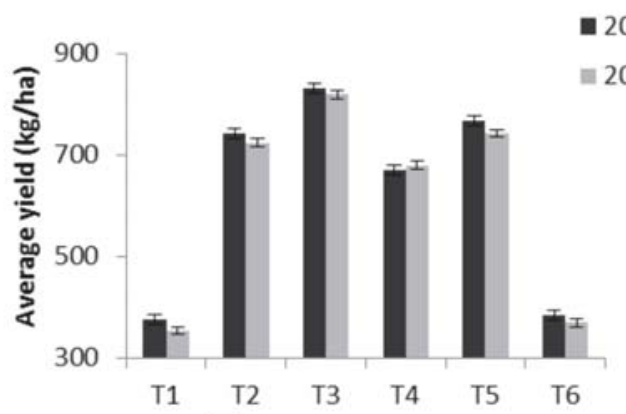

(e) Treatments

Fig. 1. Plant parameters under different treatments (a) average plant height, (b) average plant dry weight, (c) average plant root length, (d) average $\% \mathrm{~N}$ in plants, (e) average yield

No marked difference in trend was found during the course of investigation in respect of total yield obtained across the six different treatments, however, yields were reduced over time from 2008 to 2014. Average grain yield was obtained highest in plants treated with $100 \% \mathrm{~N}$ applied through FYM (831 kg/ha and $819 \mathrm{~kg} / \mathrm{ha})$ followed by application of recommended dose of fertilizer (743 $\mathrm{kg} / \mathrm{ha}$ and $723 \mathrm{~kg} / \mathrm{ha}$ ) during 2008 and 2014, respectively, which was significantly higher over control $\left(T_{1}\right)$ and farmers' practice $\left(T_{6}\right)$ treatments (Fig. 1e).

Soil parameters: Available soil moisture content was one of the key parameters for disease development because it regulates nutrient mobility and availability to the plants, especially nitrogen. It was found to follow a decreasing trend in soil from 2008 to 2014 . Experimental soil subjected to continuous application of $100 \% \mathrm{~N}$ through FYM $\left(\mathrm{T}_{3}\right)$ were shown maximum available soil moisture $(31.0 \%$ and $27.8 \%)$ content followed by soils treated with recommended dose of fertilizer $\left(\mathrm{T}_{2}\right)$ (Fig. 2a).

Nitrate-nitrogen $\left(\mathrm{NO}_{3}-\mathrm{N}\right)$ content in soil was another substantial key parameter for disease development in our study. It was found to vary over the period of experiment with highest level $(22.17 \mathrm{~kg} / \mathrm{ha}$ and 20.17 $\mathrm{kg} / \mathrm{ha}$ ) under application of $100 \% \mathrm{~N}$ through FYM followed by recommended dose of fertilizer use, i.e., $17.03 \mathrm{~kg} / \mathrm{ha}$ and $15.33 \mathrm{~kg} / \mathrm{ha}$ in 2008 and 2014, respectively, which followed a decreasing trend during the course of time (Fig. 2b). The lesser its availability, the more it was congenial environment to cause infection by both the fungus and nematode.

Nematode and fungus population: Root knot nematode (Meloidogyne incognita) density was found to vary among different sources of nitrogen used for the growth and development of crops. In the observations taken in 2008, nematode density of control plot was just doubled than plots where $100 \% \mathrm{~N}$ was applied in the form of FYM. Interestingly, the total number of nematodes was found to follow an increasing trend from 2008 to 2014 in all the cases (Fig. 3a). But, maximum density was always found in control i.e., 376 per $500 \mathrm{~g}$ soil and 417 per $500 \mathrm{~g}$ soil during both the years.

The population of Fusarium oxysporum in soil varied significantly in different treatments, though lowest 

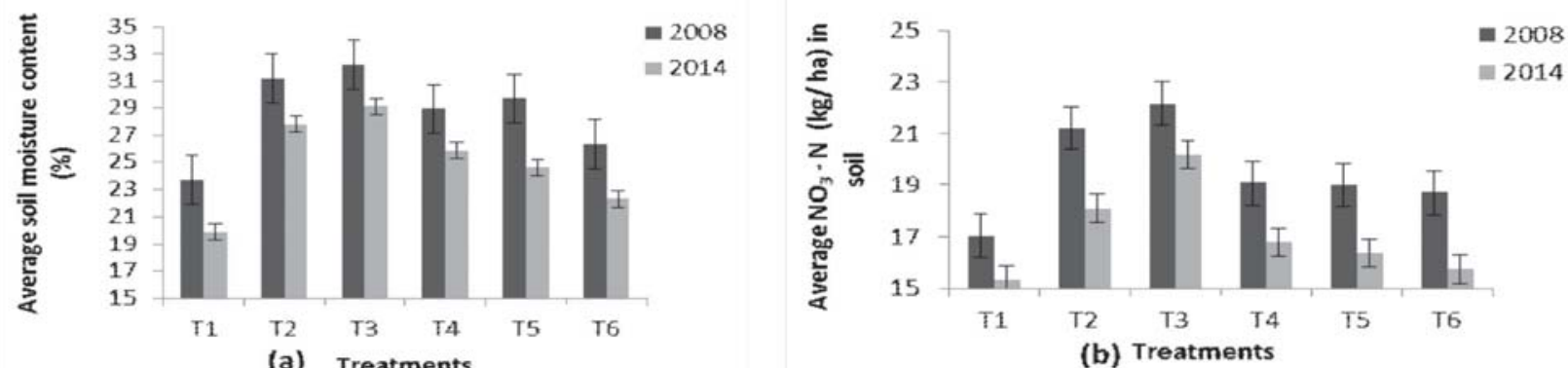

Fig. 2. Soil parametes under different treatments (a) average soil moisture content, (b) average $\mathrm{NO}_{3}-\mathrm{N}$ content

population density was found in $\mathrm{T}_{3}(100 \% \mathrm{FYM}$ treatment). Nevertheless population buildup of fungus in soil followed an increasing trend over 2008 to 2014 (Fig. 3b).

Disease severity index: Disease severity index in this experiment was significantly affected by source of nitrogen used throughout the crop growing period. Mean disease severity index was found minimum in $\mathrm{T}_{3}$ (35.03 and 43.47) when compared to control (48.73 and 72.16) during 2008 and 2014 (Fig. 3c). Simultaneous infection of both the fungus and nematode under low level of soil moisture and available nitrogen was favorable for increasing disease severity during the course of investigation.

It was very clear from the above study that low soil moisture and $\mathrm{NO}_{3}-\mathrm{N}$ content of different treatments is the fundamental reason for higher disease severity index of wilt nematode complex in lentil during 2008 and 2014. The significantly high negative correlation coefficient value $(r=-0.92$ for 2008 and $r=-0.86$ for 2014$)$ between soil moisture content and disease severity index indicates their inverse relationship (Fig. 4 a,b).

\section{DISCUSSION}

The interrelationship of different environmental factors, edaphic factors and plant nutrition in disease development is well established. In this paper we report the severity of wilt-nematode disease complex due to simultaneous infection of F. oxysporum and M. incognita on lentil is increased significantly by low available soil moisture and nitrogen. Further, the disease complex is less intensive when nitrogen is applied through FYM. Among different nitrogen sources, long term application of FYM in soil contributed to lowering the disease severity along with the soil population of wilt fungus F. oxysporum and nematode $M$. incognita (Singh et al., 2014). Synergism in disease severity due to concomitant nematode and fungus attack has been reviewed extensively (Razdan et al., 2013). The soil moisture regime, temperature vis-à-vis nutrient mobility and uptake pattern play a significant role in buildup nematode population as well as symptom expression and fungal growth in Fusarium wilt of lentil.

The $\% \mathrm{~N}$ content in plants and concentration of $\mathrm{NO}_{3}-$ $\mathrm{N}$ in soil were reduced over time scale 2008 to 2014; though significant difference in level was noted among

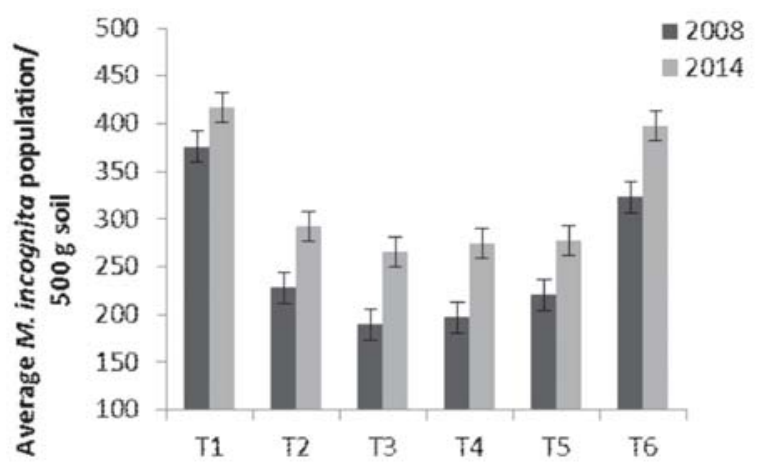

(a) Treatments

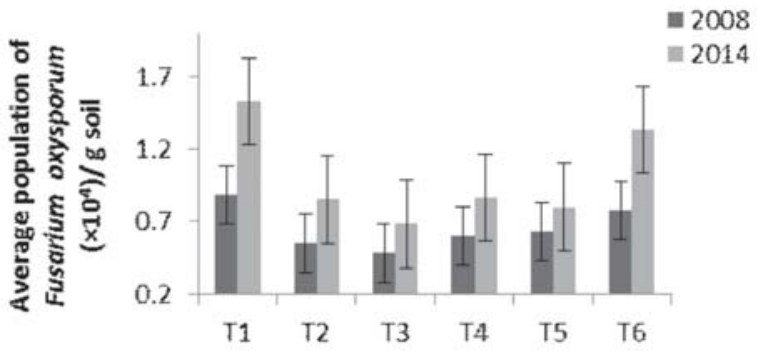

(b) Treatments

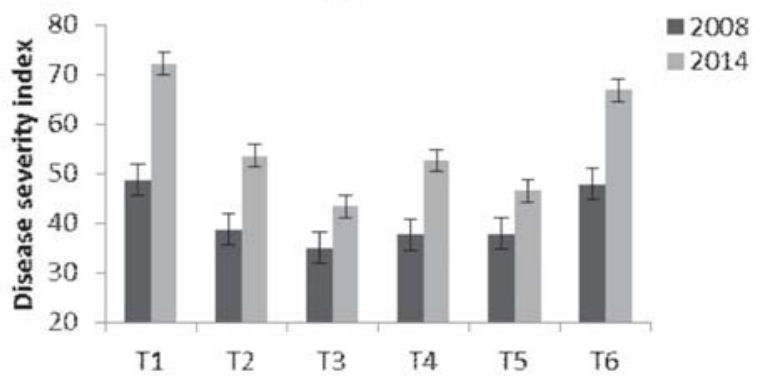

(c) Treatments

Fig. 3. Disease parameters (a) average population of $M$. incognita, (b) average population of Fusarium oxysporum, (c) disease severity index

treatments i.e., source of nutrition. The available water content and soil moisture regime were found to decrease over the years (2008-2014). The fungus and nematode population increases in soil over time indicating a possible build up due to low level of available $\mathrm{N}$ and soil moisture. Decrease in soil moisture results in decreased availability of $\mathrm{NO}_{3}-\mathrm{N}$ to plants resulting in lowering the yield and yield attributes mainly because of low mass flow process and less activity of nitrifying bacteria in soil which corroborates with the findings of Singh (2009) where, 

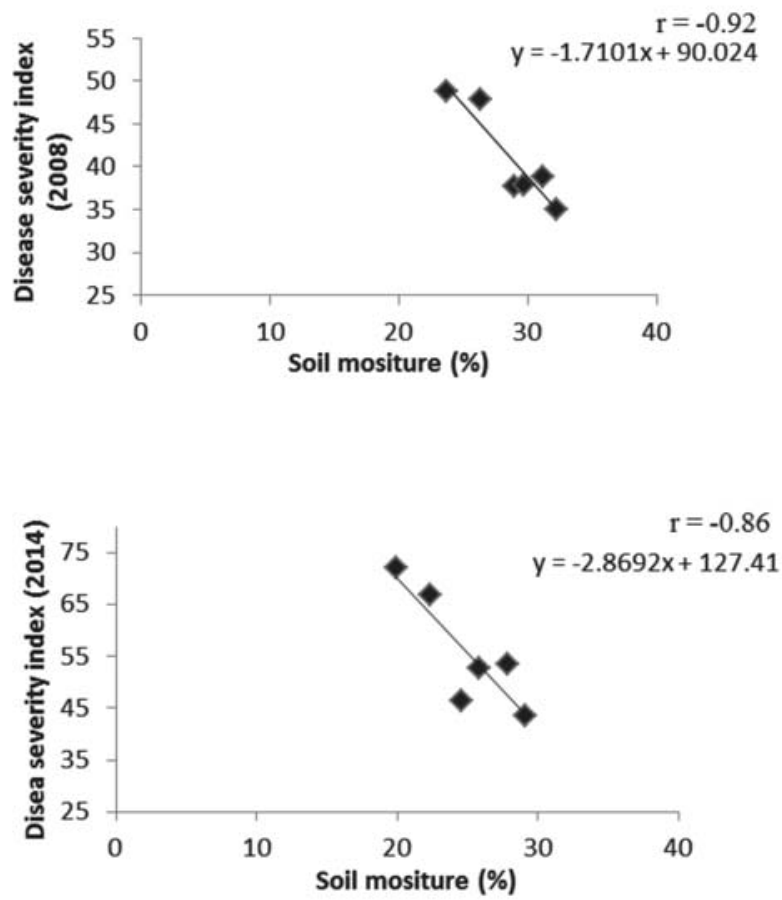

Fig. 4. Correlation between disease severity index and available soil moisture content (a) 2008, (b) 2014

Fusarium wilt of tomato due to coinfection of nematode and fungus has been found to decrease with increasing level of nitrogen. The population of both nematode and fungus vis-à-vis disease severity in plants was found to be the lowest when supplied with $100 \% \mathrm{~N}$ through FYM. On the other hand the nitrate content in soil and average $\% \mathrm{~N}$ level in plants were found to be highest in plots treated with FYM. Significantly higher moisture retention was found in the plots where entire $\mathrm{N}$ was applied continuously through FYM. Maximum dry weight of plants was found in plots treated with recommended fertilizer dose while the yield was at par with plots treated with FYM continuously. It indicates FYM can be used as an option for managing wilt severity in lentil in 'transect 4' of the Indo Gangetic Plain (IGP) region.

Our result supports the evidence of relation among disease severity, nitrate nitrogen present in soil, content of $\% \mathrm{~N}$ in plants and moisture level in soil to yield attributing traits like plant height, average root length, average dry weight and average yield of lentil crop grown in rabi after rice under rainfed condition.

\section{ACKNOWLEDGEMENTS}

This work was supported by the ICAR in granting AICRP on Dry land Agriculture to BHU, Varanasi. We thank Project coordinator and Director, CRIDA, Hyderabad for technical support. The additional financial support of ICAR in granting Extramural project NRM.11 (16)/2015AFC (19) to Nirmal De is gratefully acknowledged.

\section{REFERENCES}

Black CA (1965). Methods of Soil Analysis: Part I physical and mineralogical properties. American Society of Agronomy, Madison, Wisconsin, USA.

De RK, Ali SS and Dwivedi RP (2001). Effect of interaction between Fusarium oxysporum f. sp. lentis and Meloidogyne javanica on lentil. J. Fd. Legume 14: 71-73.

Ge P, Da LJ, Wang WB and Xu XN (2014). Seasonal dynamics of dissolved organic carbon, nitrogen and other nutrients in soil of Pinus massoniana stands after pine wilt disease disturbance. J. Soil Sci. Plant Nutr. 14: 201-209.

Goswami BK, Pandey RK, Goswami J and Tiwari DD (2007). Management of disease complex caused by root-knot nematode and wilt fungus on pigeon pea through soil organically enriched with Vesicular Arbuscular Mycorrhizae, Karanz (Pongamia pinnata) oil seed cake and farmyard manure. J. Environ. Sci. Health, Part B. 42: 899904.

Govaerts B, Mezzalama M, Sayre DK, Crossa J, Litcher K, Torch V, Vankerck K, Corte DP and Deckers J (2008). Long term consequences of tillage, residue management and crop rotation on selected soil microflora groups in the Subtropical Highlands. Appl. Soil Ecol. 38: 197-210.

Jackson ML (1973). Soil Chemical Analysis, Prentice Hall of India Pvt. Ltd., New Delhi.

Mary NE, Emmanuel I, Oyema N, Yoila SA and Victoria MB (2013). Effect of long term soil management practices on nematode population in an Alfisol under continuous maize in Northern Guinea Savanna of Nigeria. Int. J. Agric. Pol. Res. 1: 80-88.

Rao VN, Sastry RK, Craufurd P, Meinke H, Parsons D, Rego TJ and Rathore A (2014). Cropping system strategy for effective management of Fusarium wilt in safflower. Field Crops Res. 156: 191-198.

Razdan VK, Gupta V and Gupta V (2013). Wilt intensity on brinjal crop due to the interaction of various soil borne pathogens. Indian Phytopath. 66: 269-272.

Rolf AO and Bakken LR (1987). Viability of Soil Bacteria: Optimization of plate counting technique and comparison between total counts and plate counts within different size groups. Microb. Ecol. 13: 59-74.

Schindler AF (1961). A simple substitute for a Baermann funnel. Plant Dis. Rep. 45: 747-748.

Sherwood RT and Hagedorn DJ (1958). Determining the common root rot potential of pea fields. Bull. Wisconsin Agric. Exp. Sta. 12: 531.

Singh RS (2009). Plant Diseases. Oxford and IBH, New Delhi.

Singh N, Maheshwari MN, Chaudhari SM and Patel DJ (2014). Integrated management of root-knot nematode (Meloidogyne incognita) in potato. Indian Phytopath. 67: 418-422.

Stoilova S and Chavdarov P (2006). Evaluation of Lentil germplasm for diseases Resistance to Fusarium wilt (Fusarium oxysporum f.sp. lentis). J. Cent. Eur. Agric. 7: 121-126.

Yu YT, Liu HL, Zhu AL, Zhang G, Zeng LB and Xue SD (2012). A review of root lesion nematode: identification and plant resistance. Adv. Microbiol. 2: 411-416. 